\title{
Crude protein reduction and digestible methionine+cystine and threonine to digestible lysine ratios in diets for Nile tilapia fingerlings ${ }^{1}$
}

\author{
Moisés Quadros ${ }^{2}$, Eduardo Arruda Teixeira Lanna ${ }^{3}$, Juarez Lopes Donzele ${ }^{3}$, Márvio Lobão \\ Teixeira de Abreu4${ }^{4}$, Felipe Barbosa Ribeiro², Sylvia Sanae Takishita ${ }^{2}$

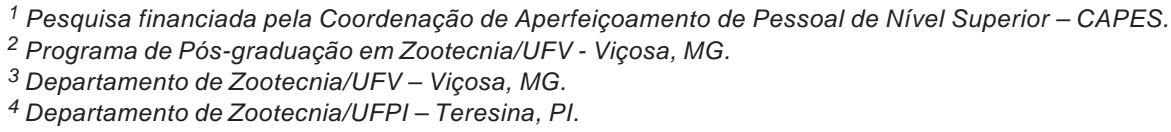

ABSTRACT - The objective of the present study was to investigate crude protein reduction and the methionine+cystine and threonine to lysine ratios in diets for reversed Nile tilapia fingerlings (Oreochromis niloticus), Thai strain. Four hundred and twenty Nile tilapia fingerlings with an average initial weight of $1.83 \pm 0.02 \mathrm{~g}$ were placed in a completely randomized design, with five treatments, seven replications per treatment and 12 fish per experimental unit, for 37-days. Two crude protein (CP) levels were evaluated (32 and 28\%). The diet with 32\% CP had methionine+cystine:lysine and threonine:lysine ratios of 63 and $74 \%$, respectively. Three diets with 28\% CP had methionine+cystine:lysine and threonine:lysine ratios of 63 and 74\%, 60 and $74 \%$ and 60 and 69\%, respectively. The diet with 28\% CP and had methionine+cystine:lysine ratio of $63 \%$ and threonine:lysine of $74 \%$ and was supplemented with $0.3 \%$ glutamic acid. The fish were kept in thirty-five $130 \mathrm{~L}$ aquariums supplied with single-pass flow-through water, individual aeration and fed ad libitum six times per day. Fish fed the diet with 32\% CP had lower protein efficiency ratios and nitrogen efficiency ratios. The diet CP level was $28 \%$ and the methionine+cystine and threonine to lysine ratios were 60 and $69 \%$, respectively.

Key Words: digestible lysine, ideal protein, Oreochromis niloticus, synthetic amino acids

\section{Redução de proteína bruta e relações de metionina+cistina e treonina digestíveis com lisina digestível em dietas para alevinos de tilápia-do-nilo}

\begin{abstract}
RESUMO - Objetivou-se avaliar a redução do nível de proteína bruta e as relações dos aminoácidos metionina+cistina e treonina digestíveis com a lisina digestível em dietas para alevinos revertidos de tilápia-do-nilo (Oreochromis niloticus), da linhagem tailandesa. Um experimento com duração de 37 dias foi realizado utilizando-se 420 alevinos com peso inicial de 1,83 \pm 0,02 g, distribuídos em delineamento inteiramente ao acaso, composto de 5 dietas, 7 repetições e 12 peixes por unidade experimental. Foram avaliados dois níveis de PB (32 e 28\%) em diversas dietas experimentais. Na dieta com 32\% de $\mathrm{PB}$, foram mantidas as relações de metionina+cistina e treonina com lisina de 63 e $74 \%$, respectivamente; nas três dietas com 28\% de $\mathrm{PB}$, as relações de metionina+cistina e treonina com lisina foram de 63 e $74 \%$, 60 e $74 \%$ e 60 e $69 \%$, respectivamente; e, na dieta com $28 \%$ de $\mathrm{PB}$, as relações de metionina+cistina e treonina com lisina foram de 63 e $74 \%$, respectivamente, porém com acréscimo de 0,3\% de ácido glutâmico. Os peixes foram mantidos em 35 aquários de 130 litros, com abastecimento de água, aeração individual e alimentação à vontade em seis refeições diárias. Os peixes mantidos com a dieta com 32\% de PB apresentaram menores eficiências de retenção de proteína e de nitrogênio. O nível de PB de rações para alevinos de tilápia-do-nilo deve ser de $28,0 \%$ e as relações de metionina+cistina digestível e treonina digestível com a lisina, de 60 e $69 \%$, respectivamente.
\end{abstract}

Palavras-chave: aminoácidos sintéticos, lisina digestível, Oreochromis niloticus, proteína ideal

\section{Introduction}

The rapid expansion of aquaculture and advances in fish farming techniques has increased the demand for balanced diets (Watanabe et al., 2002). However, the achievement of high productivity should be reconciled with the reduction in waste discharge into the aquatic environment, mainly nitrogen and phosphorus, responsible for body of water eutrophication (Furuya et al., 2005; Lanna et al., 2005). 
The great expansion of intensive tilapia farming in earth ponds, recirculation or flow-through water systems, as well as in cages, where the use of diets is the main source of nutrients, tends to raise the nitrogen level excreted to the environment. This problem can be reduced by decreasing the concentration of the protein diet and supplementation of limiting amino acids without affecting the fish development and performance (Boisen, 2003; Yamamoto et al., 2005).

To formulate diets based on the ideal protein concept, which results in lower nitrogen excretion to the environment, and to estimate fish amino acid requirements, it is necessary to reduce the diet protein level (Bomfim et al., 2005a; Furuya et al., 2005).

The determination of the lysine dietary requirements, methionine (methionine + cystine) and threonine can have great impact on tilapia production, since these amino acids are limiting in the majority of feed-stuff used to replace fish meal, such as soybean meal and corn gluten. However, currently they are accessible and their use is economically viable in diets with low protein level. Moreover, amino acids are involved in the intermediary metabolism of various compounds responsible for various functions in the animal's system, such as mucin, which has a high level of threonine, immunoglobulin (cystine and threonine) and glutathione (cysteine) (De Blas et al., 2000, Machado \& Fontes, 2005).

As the amino acid requirements, usually expressed as diet protein level percentage or as diet percentage, were obtained from results of a few experiments, more studies are needed to validate the recommendations (Hauler \& Carter, 2001; Wilson, 2003).

The objective of the present study was to investigate the crude protein reduction and the digestible methionine+ cystine and threonine to digestible lysine ratios in diets for Nile tilapia fingerlings, based on the ideal protein concept.

\section{Material and Methods}

This study was undertaken during 37 days between August and September 2006, at the Laboratório de Nutrição de Peixes of the Departamento de Zootecnia of the Universidade Federal de Viçosa.

Four hundred and twenty Nile tilapia (Oreochromis niloticus) fingerlings, Thai strain, with an average initial weight of $1.83 \pm 0.02 \mathrm{~g}$, were placed in a complete randomized design, with five diets, seven replications per diet and 12 fish per experimental unit. The experimental diets were isocaloric (3.000 kcal digestible energy) and isolysinic (1.7\%), with 32 or $28 \%$ CP.
The diet with 32\% of CP had methionine+cystine:lysine and threonine:lysine ratios of 63 and 74\%, respectively, and had no supplementation of L-lisina-HCL, but the other synthetic amino acids were added as their ratios with digestible lysine were below those estimated in the ideal protein, calculated from the requirement values determined by the NRC (1993).

Four diets contained 28\% CP and were formulated with different amino acids ratios: one of the diets with $28 \% \mathrm{CP}$ had the same dietary amino acids ratios as the diet with $32 \%$ $\mathrm{CP}$; another diet was formulated keeping the threonine:lysine ratio, but changing the methionine + cystine:lysine ratio to $60 \%$, according to the recommendations of Furuya et al.(2004) and Bomfim et al. (2007); a third diet was formulated with the same crude protein level and the same methionine + cystine ratio as the previous diet, but the threonine:lysine ratio was changed to $69 \%$, according to the recommendations of Lanna et al. (2007); and, finally, the fourth diet with $28 \%$ $\mathrm{CP}$ was formulated with methionine + cystine and threonine to lysine ratios of 63 and $74 \%$ respectively, but $0.3 \%$ glutamic acid was added to verify a possible non-essential amino acid deficiency.

The percentage and chemical compositions of the experimental diets were calculated according to Rostagno et al. (2005) and Furuya et al. (2001) (Table 1).

The digestible amino acid and available phosphorus values were estimated based on ingredient digestibility coefficients according to Rostagno et al. (2000) and Furuya et al. (2001), energy, according to Boscolo et al. (2002) and Pezzato et al. (2002), and the dietary amino acid analyses were performed in the Laboratório da Ajinomoto, in Brazil. The calculated and analyzed amino acids values differed, probably due to the feedstuff composition variations.

Fingerlings were kept in 36 polyethylene aquariums, each one with a volumetric capacity of 150 liters and net volume of 130 liters, with individual aeration systems, single-pass flow-through water supply and draining from the bottom, arranged in a water recirculation system with renewal of at least $25.0 \%$ water per day.

The aquarium water supply came from the water treatment system of Universidade Federal de Viçosa - UFV, previously declorified and heated by electrical resistance, with temperature controlled by thermostat.

The water temperature was kept at approximately $28^{\circ} \mathrm{C}$ and checked daily at 7:30 a.m. and 5:30 p.m., using an electronic thermometer. The water $\mathrm{pH}$ and dissolved oxygen levels were controlled every seven days using a potentiometer and oximeter. 
Table 1 - Composition of the experimental diets (as fed)

\begin{tabular}{|c|c|c|c|c|c|}
\hline Item & \multicolumn{5}{|c|}{ Crude protein level and amino acid ratios (\%) } \\
\hline \multicolumn{6}{|l|}{ Ingredient (\%) } \\
\hline Soybean meal & 65.342 & 53.500 & 53.480 & 53.560 & 53.500 \\
\hline Corn & 26.167 & 36.594 & 36.509 & 36.588 & 36.594 \\
\hline Corn starch & 1.000 & 1.922 & 2.022 & 1.922 & 1.673 \\
\hline Soybean oil & 3.122 & 2.843 & 2.844 & 2.829 & 2.793 \\
\hline DL-methionine - 99\% & 0.197 & 0.308 & 0.257 & 0.308 & 0.308 \\
\hline L-threonine - 98,5\% & 0.139 & 0.305 & 0.306 & 0.216 & 0.305 \\
\hline L-tryptophan - 99\% & 0.000 & 0.010 & 0.063 & 0.062 & 0.010 \\
\hline Glutamic acid - 99\% & 0.000 & 0.000 & 0.000 & 0.000 & 0.300 \\
\hline Dicalcium phosphate & 2.960 & 3.100 & 3.100 & 3.100 & 3.100 \\
\hline Vitaminic and mineral $\operatorname{mix}^{4}$ & 0.500 & 0.500 & 0.500 & 0.500 & 0.500 \\
\hline Vitamin $C^{5}$ & 0.050 & 0.050 & 0.050 & 0.050 & 0.050 \\
\hline Crude protein (\%) & 32.0 & 28.0 & 28.0 & 28.0 & 28.2 \\
\hline Digestible energy (kcal/kg) & 3,000 & 3,000 & 3,000 & 3,000 & 3,000 \\
\hline Total calcium $(\%)$ & 0.9 & 0.9 & 0.9 & 0.9 & 0.9 \\
\hline Dicalcium phosphate (\%) & 0.6 & 0.6 & 0.6 & 0.6 & 0.6 \\
\hline Digestible lysine (\%) & 1.7 & 1.7 & 1.7 & 1.7 & 1.7 \\
\hline Digestible tryptophan (\%) & 0.4 & 0.3 & 0.4 & 0.4 & 0.3 \\
\hline Digestible isoleucine (\%) & 1.3 & 1.1 & 1.1 & 1.1 & 1.1 \\
\hline Met + cys/Lys ratio (\%) & 63.0 & 63.0 & 60.0 & 60.0 & 63.0 \\
\hline Thr/lys ratio(\%) & 74.0 & 74.0 & 74.0 & 69.0 & 74.0 \\
\hline \multicolumn{6}{|l|}{ Nutritional (analyzed) ${ }^{7}$} \\
\hline Crude protein (\%) & 33.02 & 28.81 & 28.20 & 29.09 & 28.41 \\
\hline
\end{tabular}

${ }^{1}$ Methionine + cystine to lysine ratio of $60 \%$ (Furuya et al., 2004; Bomfim et al., 2007).

2 Threonine to lysine ratio of $69 \%$ (Lanna et al., 2007).

3 Suplemented with $0.3 \%$ glutamic acid.

${ }^{4}$ Composition per kilogram of product: vitamin A - 1.200.000 UI; vitamin $\mathrm{D}_{3}$ - $200.000 \mathrm{UI}$; vitamin $\mathrm{E}$ - 1.200 mg; vitamin $\mathrm{K}_{3}$ - 2.400 mg; vitamin $\mathrm{B}_{1}-4$,800 mg; vitamin $\mathrm{B}_{2}$ - $4.800 \mathrm{mg}$; vitamin $\mathrm{B}_{6}-4.800 \mathrm{mg}$; vitamin $\mathrm{B}_{12}$ - $4.800 \mathrm{mg}$; vitamin $\mathrm{C}$ - 48 g; folic acid - 1.200 mg; panthotenic acid - 12.000 mg; biotin - 48 mg; cholin - 108 g; niacin - 24.000 mg; Fe - 50.000 mg; Cu - 3.000 mg; Mn - 20.000 mg; Zn - 30.000 mg; I - 100 mg; Co - 10 mg; Se - 100 mg.

5 Vitamin C: calcic salt, 2- ascorbic acid monophosphate - $42 \%$ active principle.

${ }^{6}$ Estimated values based on the digestibility coefficients of the ingredients for the amino acids, phosphorus according to Rostagno et al. (2000) and Furuya (2001), and energy according to Boscolo et al. (2002) and Pezzato et al. (2002).

7 Ajinomoto Animal Nutrition Laboratory (Brazil).

The photoperiod was kept at 12 hours light using mixing light bulbs, controlled by an automatic timer.

The experimental diets were pelletized and provided daily in six meals at 8 a.m., 10 a.m., 12 p.m., 2 p.m., 4 p.m. and 6 p.m., so that at each meal the food was supplied several times in small quantities to enable maximum intake, without losses, until apparent satiation, to reduce the leaching possibility.

The aquariums were cleaned once a day by siphoning the excreta, always after reading the water temperature in the afternoon.

The following indexes were evaluated: feed intake, lysine consumption, nitrogen consumption, weight gain, specific growth rate, survival rate, feed/gain ratio, protein efficiency for growth, lysine efficiency for growth, protein and body fat daily deposition, body composition (humidity, protein and fat), hepatosomatic index (HSI), carcass yield and nitrogen retention efficiency.

Protein and lysine efficiency for growth were calculated by dividing the weight gain by crude protein or digestible lysine consumption, respectively, according to the expressions described by Jauncey \& Ross (1982).

At the beginning of the experimental period, 80 fish were sacrificed, after being anesthetized, for body analysis and, at the end of the trial, eight animals were sacrificed per experimental unit with weights closest to the average to their respective unit. 
The viscera and liver weights were obtained after removing the viscera to determine the whole carcass yield (with head and fins). Viscera were weighed in an analytical scale $(0.001 \mathrm{~g})$ to determine the percentage of viscera in the body and the IHS.

The chemical analyses of diets and fish samples were performed at the Laboratório de Nutrição Animal of the Departamento de Zootecnia of the Universidade Federal de Viçosa, using the methodology reported by Silva \& Queiroz (2002), so that that the body humidity was determined by the lyophilization process.

The body protein and fat depositions were calculated by the difference between the initial and final body protein or fat, respectively, in milligrams, divided by the experimental period (days). The nitrogen retention efficiency, expressed in percentage, was calculated by the difference between the final and initial body nitrogen, divided by the total nitrogen consumed and multiplied by 100 .

The statistical analysis was performed using the SAEG program - Sistemas de Análises Estatísticas e Genéticas (UFV, 2000). The data were analyzed by analysis of variance at the level of $5.0 \%$ probability and, when there was statistical difference, for the comparison of the obtained means, the Student Neuman Keuls test was used (SNK).

\section{Results and Discussion}

The water and aeration system allowed the control of temperature and aeration during the experimental period. Values of $28.0 \pm 0.90^{\circ} \mathrm{C}$ for water temperature, $7.1 \pm 0.20$ for $\mathrm{pH}, 7.4 \pm 0.40 \mathrm{ppm}$ for dissolved oxygen and $0.90 \pm 0.06 \mathrm{mg} / \mathrm{L}$ ammoniac nitrogen were maintained. These values correspond to the range recommended for the production of this species, according to Kubitza (2000).
The reduced diet crude protein level did not influence $(\mathrm{P}<0.05)$ weight gain, specific growth rate, the fish survival rate and feed and digestible lysine intake (Table 2).

These results are similar to those reported by Bomfim et al. (2006). There was also no statistical difference $(\mathrm{P}<0.05)$ in these parameters among fish fed the diets with different amino acids ratios. Contrary to that observed by Bomfim et al. (2006), there was a numerical increase in weight gain and feed intake of fish fed the diet with the lowest crude protein level (28\%) compared to values obtained with the control diet (32\%).

There was no difference $(\mathrm{P}<0.05)$ in average feed intake among the diets, therefore, the one with the highest $\mathrm{CP}$ level resulted in greater nitrogen intake, lower protein efficiency for growth and nitrogen retention efficiency rates $(\mathrm{P}<0.05)$. However, fish fed diets with lower protein levels and different amino acids ratios did not differ $(\mathrm{P}<0.05)$ for the same parameters.

These results prove that, as described by Halver \& Hardy (2002), the preparation of diets for fish using the "ideal protein" concept can reduce nitrogen compound emission to the bodies of water adjacent to fish farms, which with phosphorus, are primarily responsible for algal blooms that lead to eutrophication of ecosystems (Wilson, 2003; Bomfim et al., 2005a). This increased efficiency of the diet protein fraction use may also affect the production cost since the protein is the most expensive component of the diet - and reduce the total ammoniac nitrogen concentration, which, depending on the water $\mathrm{pH}$, can damage productivity and increase mortality (Losordo, 1997).

All diets provided specific growth rates of approximately $5.5 \%$ per day, which were similar to those observed by Hisano et al. (2003), Furuya et al. (2006) and Ribeiro et al. (2006) with tilapia of the same strain and the same weight

Table 2 - Performance of Nile tilapia fingerlings fed experimental diets

\begin{tabular}{|c|c|c|c|c|c|c|}
\hline \multirow[t]{2}{*}{ Item } & \multicolumn{5}{|c|}{ CP level and a mino acid ratios (\%) } & \multirow[b]{2}{*}{ CV (\%) } \\
\hline & 32 (NRC, 1993) & 28 (NRC, 1993) & 28 (Met.+Cys.) $^{1}$ & $28(\text { Thr. })^{2}$ & $28(\mathrm{NRC}, 1993)^{3}$ & \\
\hline Initial weight (g) & 1.83 & 1.84 & 1.83 & 1.82 & 1.82 & 1.16 \\
\hline Weight gain (g) & 12.17 & 12.26 & 12.46 & 12.40 & 12.17 & 8.82 \\
\hline Specific growth rate (\%/dia) & 5.49 & 5.50 & 5.55 & 5.56 & 5.51 & 3.59 \\
\hline Survival rate (\%) & 100.00 & 98.81 & 100.00 & 100.00 & 98.81 & 2.00 \\
\hline Feed intake (g) & 14.92 & 15.06 & 15.34 & 15.53 & 15.29 & 4.91 \\
\hline Digestible lysine intake (mg/dia) & 6.86 & 6.92 & 7.05 & 7.13 & 7.03 & 4.91 \\
\hline Nitrogen intake (mg/dia) & $20.65 a$ & $18.23 b$ & $18.57 b$ & $18.80 \mathrm{~b}$ & $18.52 b$ & 5.00 \\
\hline Feed/gain ratio (g/g) & 1.23 & 1.24 & 1.22 & 1.25 & 1.26 & 5.98 \\
\hline Protein efficiency for growth (g/g) & $2.54 b$ & $2.90 \mathrm{a}$ & $2.90 \mathrm{a}$ & $2.85 a$ & $2.84 \mathrm{a}$ & 5.80 \\
\hline Lysine efficiency for growth (g/g) & 47.74 & 47.83 & 47.82 & 46.95 & 46.76 & 5.77 \\
\hline
\end{tabular}

${ }^{1}$ Methionine + cystine to lysine ratio of $60 \%$ (Furuya et al., 2004; Bomfim et al., 2007).

2 Threonine to lysine ratio of $69 \%$ (Lanna et al., 2007).

${ }^{3}$ Supplemented with $0.3 \%$ glutamic acid.

Means, in the same line, followed by different letters, differ $(\mathrm{P}<0.05)$, by SNK test. 
category. However, the values were lower than those found by Bomfim et al. (2005 a) and Bomfim et al. (2005b), which were $7.0 \%$ per day, the rate of $7.8 \%$ reported by Lanna et al. (2005) and 8.7\% per day observed by Furuya et al. (2000).

Fish growth rates indicated that the handling used in this experiment and the diets supplemented with free amino acids, even with lower levels of crude protein compared to the requirement of $32 \%$ for the species, according to Furuya et al. (2000), were sufficient to enhance the animals' performance. The "ideal protein" concept has been tested in other species and allows keeping animals performance by reducing the diet protein level through free amino acids supplementation. Yamamoto et al. (2005) obtained similar results in a study with trout.

The protein efficiency for growth (PEG) did not vary among between fish fed diets with 28\% CP and different amino acid:lysine ratios, but was higher in absolute value, to that obtained with the $32 \%$ CP diet. Similar results were found by Bomfim et al. (2005a), Furuya et al. (2005) and Bomfim et al. (2006), but the results in this study were higher than those observed by Hisano et al. (2003), Boscolo et al. (2006) and Furuya et al. (2006).

This higher PEG may be related to the better amino acid balance of the diet, due to the reduction of amino acid excess in relation to the animal requirement in the diet with higher protein level, that probably would not contribute to the accumulation of lean tissue and were catabolized (Bomfim et al., 2005a; Bomfim et al., 2005b; Bomfim et al., 2006). On the other hand, the absence of significant difference between the means for diets with lower protein level indicated that the ratio of methionine + cystine and threonine to lysine may be lower than those recommended by NRC (1993). It also indicated that in this study, the increase of $0.3 \%$ glutamic acid in the diet with $28 \% \mathrm{CP}$ and ratios of 63 and $74 \%$ methionine + cystine and threonine to lysine, respectively, caused no differences $(\mathrm{P}<0.05)$ in performance and probably there was no deficiency in any non-essential amino acid, contrary to the report by Schumacher et al. (1995) who observed that a source of non-essential amino acids (glutamic acid) had a highly significant effect on rainbow trout growth.

These results suggested that diets formulated based on the ratios between digestible amino acids and lysine may be more appropriate to meet the requirements of tilapia than those made solely based at the crude protein level(Boisen, 2003, Orlando et al., 2005; Bomfim et al., 2005a; Bomfim et al., 2006).

There were no differences $(\mathrm{P}<0.05)$ between the average performance of animals fed different diets, a result which differed from that reported by Bomfim et al. (2005a), who observed worsening in the feed/gain ratio and lysine use efficiency for growth of fish fed low protein diets supplemented with synthetic amino acids.

This negative result has been attributed to some problems in the use of diets supplemented with an excess of synthetic amino acids, such as the possibility of greater leaching of synthetic amino acids compared to those of vegetable protein in the aquatic environment and the imbalance of the ideal amino acid profile on the sites of protein synthesis due to its higher rate of absorption (Zarate\&Lovell, 1997,Zarateetal., 1999, Dabrowski etal., 2003; Lanna et al., 2005).

In this study, the deleterious effects of the synthetic amino acids use may have been minimized by the increased of feed frequency, six times per day in small amounts and several times in each hour to ensure rapid and complete intake of the diets, which may have reduced the leaching and contributed to the stabilization of the amino acid plasma concentration and balance of the amino acid pool on the sites of protein synthesis, reducing its catabolism

Table 3 - Performance and carcass indices of Nile tilapia fingerlings fed experimental diets

\begin{tabular}{|c|c|c|c|c|c|c|}
\hline \multirow[t]{2}{*}{ Item } & \multicolumn{5}{|c|}{ CP level and a mino acid ratios (\%) } & \multirow[b]{2}{*}{ CV $(\%)$} \\
\hline & 32 (NRC, 1993) & 28 (NRC, 1993) & $28{\text { (Met.+Cys. })^{1}}$ & 28 (Thr.) $)^{2}$ & $28(\mathrm{NRC}, 1993)^{3}$ & \\
\hline Body humidity (\%) & 81,7 & 75,7 & 74,7 & 74,8 & 75,6 & 74,2 \\
\hline Body crude protein $(\%)^{4}$ & 7,5 & 11,3 & 11,7 & 11,6 & 11,3 & 12,0 \\
\hline Fat deposition (mg/dia) & - & 17,73 & 17,96 & 19,11 & 19,37 & 18,19 \\
\hline Protein deposition (mg/dia) & - & 38,88 & 40,80 & 40,77 & 39,91 & 41,37 \\
\hline Nitrogen retention efficiency (\%) & - & $30,1 b$ & $35,7 a$ & $35,5 a$ & $34,0 \mathrm{a}$ & $36,0 \mathrm{a}$ \\
\hline
\end{tabular}


and subsequent excretion (Tantikitti \& March, 1995; Zarate, 1999; Rodehutscord et al., 2000).

The reduction of the diet protein level did not influence $(\mathrm{P}<0.05)$ the carcass yield, fish body protein content, body humidity and body fat (Table 3).

These results differ from those reported by Bomfim et al. (2005a), who observed lower levels of body fat in fish fed diets containing higher protein levels than fish fed diets with lower protein levels. They are also contrary to those observed by Yamamoto et al. (2005), in research on trout. These results may be related to the amino acid excess, that was catabolized (Dabrowski \& Guderley, 2002) that may have reduced the deposition of body fat, because of the lower net energy with the higher heat increment produced (Noblet, 2001).

Fish receiving the diet with $32 \% \mathrm{CP}$ (lower digestible energy: crude protein ratio) and those fed the diet with $28 \%$ CP supplemented with glutamic acid had lower HSI (hepatosomatic index), which may be related to excess amino acid catabolism, which may have produced a higher heat increment level and resulted in a smaller fraction of net energy to be deposited as energy reserve (Bureau et al., 2000; Noblet, 2001). The metabolic activity implied the use of nutrients obtained from food intake and energy reserves held in different parts of the body. Therefore, it is expected that the weight of the liver reflects the metabolism (Costa, 1999).

The daily body fat and protein deposition did not differ $(\mathrm{P}<0.05)$ among the diets, in spite of the decrease, in absolute values, of these parameters in fish fed the diet with higher crude protein levels (32\%) compared to the values obtained with other protein levels. However, fish fed the diet with lower CP levels had higher body protein and fat deposition rates in absolute values, in relation to those fed the higher CP level, in contrast with observations by Bomfim et al. (2005a), and the lack of difference for these variables may be related to high variation coefficients.

The nitrogen retention efficiency of fish fed the diets with lower protein levels were similar $(\mathrm{P}<0.05)$ to that obtained in other studies on tilapia (Furuya et al., 2005).

These results corroborate the theory that the use of diets elaborated based on the ideal protein concept is an efficient alimentary strategy to reduce nitrogen excretion to the environment, because it does not significantly affect the animal performance(Ferreira et al., 2003; Bomfim et al., 2006).

\section{Conclusions}

The dietary crude protein level for fingerlings of Nile tilapia is $28 \%$, as long as the diets are supplemented with limiting essential amino acids. Ratios of methionine
+ cystine and threonine to digestible lysine are 60.0 and $69.0 \%$, respectively, in diets for Nile tilapia fingerlings.

\section{Literature Cited}

BOISEN, S. Ideal dietary amino acid profiles for pigs. In: D’MELLO, J.P.F. (Ed.) Amino acid in farm animal nutrition. Wallingford: CAB International, 2003. p.157-168.

BOMFIM, M.A.D.; LANNA, E.A.T.; DONZELE, J.L. et al. Redução de proteína bruta com suplementação de aminoácidos, com base no conceito de proteína ideal, em dietas para tilápia do Nilo (Oreochromis niloticus) - resultados preliminares In: REUNIÃO ANUAL DA SOCIEDADE BRASILEIRA DE ZOOTECNIA, 42. 2005, Goiânia. Anais... Goiânia, 2005a. (CD-ROM).

BOMFIM, M.A.D.; LANNA, E.A.T.; DONZELE, J.L. et al. Níveis de lisina digestível, com base no conceito de proteína ideal, em dietas para alevinos de tilápia do nilo. In: REUNIÃO ANUAL DA SOCIEDADE BRASILEIRA DE ZOOTECNIA, 43., 2006, João Pessoa. Anais... João Pessoa: Sociedade Brasileira de Zootecnia, 2006. (CD-ROM).

BOMFIM, M.A.D.; LANNA, E.A.T.; DONZELE, J.L. et al. Methionine plus cystine requirement, based on ideal protein concept, in diets for Nile tilapia (Oreochromis niloticus) fingerlings. In: Aquaculture 2007, San Antonio. Anais... San Antonio: 2007. (CD-ROM).

BOMFIM, M.A.D.; LANNA, E.A.T.; SERAFINI, M.A. et al. Proteína bruta e energia digestível em dietas para alevinos de Curimbatá (Prochilodus affins). Revista Brasileira de Zootecnia, v.34, n.6, p.1795-1806, 2005b.

BOSCOLO, W.R.; HAYASHI, C.; MEURER, F. Farinha de varredura de mandioca (Manihot esculenta) na alimentação de alevinos de tilápia do Nilo (Oreochromis niloticus L.). Revista Brasileira de Zootecnia, v.31, n.2, p.546-551, 2002.

BOSCOLO, W.R.; FEIDEN, A.; SIGNOR, A. et al. Energia digestível para alevinos de tilápia-do-nilo (Oreochromis niloticus, L.) Revista Brasileira de Zootecnia, v.35, n.3, p.629-633, 2006.

BUREAU, B.P.; AZEVEDO, P.A.; TAPIA-SALAZAR, M. et al. Pattern and cost of growth and nutrient deposition in fish and shrimp: potential implications and applications. In: CRUZSUÁREZ, L.E.; RICQUE-MARIE, D.; TAPIA-SALAZAR, M. et al. (Eds.) Avances en nutrición acuícola V. Memorias del V Simposium Internacional de Nutrición Acuícola. Mérida, Yucatán, Mexico, 2000. (CD-ROM).

COSTA A.P.R. Aspectos da biologia reprodutiva de fêmeas do Piau - Vermelho Leporinus copelandii (Steindachner, 1875) (Pisces, Anastomidae), na bacia do baixo rio Paraíba do Sul (RJ). 1999. 113f. Dissertação (Mestrado em Zootecnia) - Centro de Ciências e Tecnologia Agropecuárias/Universidade Estadual do Norte Fluminense, Campos de Goytacazes, 1999.

DABROWSKI, K; GUDERLEY, H. Intermediary metabolism. In: HALVER, J.E.; HARDY, R.W. (Eds.) Fish nutrition. 3.ed. Washington: Academic Press, 2002. p.309-365.

DABROWSKI, K.; LEE, K.; RINCHARD, J. The smallest vertebrate, teleost fish, can utilize synthetic dipeptide-based diets. Journal of Nutrition, v.133, p.4225-4229, 2003.

De BLAS, C.; GARCÍA, A.I.; CARABAÑO, R. Necesidades de treonina en animales monogástricos. In: CURSO DE ESPECIALIZACION FEDNA, 16., 2000, Madrid. Proceedings... Madrid: INRA, Uniti de Nutrition et Metabolisme Proteique, 2000. p.1-24.

FERREIRA, R.A.; OLIVEIRA, R.F.M.; DONZELE, J.L et al. Redução da proteína bruta da ração para suínos machos castrados dos 15 aos $30 \mathrm{~kg}$ mantidos em termoneutralidade. Revista Brasileira de Zootecnia, v.32, n.6, p.1639-1646, 2003.

FURUYA, W.M.; BOTARO, D.; MACEDO, R.M.G et al. Aplicação do conceito de proteína ideal para redução dos níveis de proteína em dietas para tilápia-do-nilo (Oreochromis niloticus). Revista Brasileira de Zootecnia, v.34, n.5, p.1433-1441, 2005. 
FURUYA, W.M.; BOTARO, D.; SANTOS, V.G et al. Exigências de lisina digestível para juvenis de tilápia-do-Nilo. Revista Brasileira de Zootecnia, v.35, n.3, p.937-942, 2006 (supl.).

FURUYA, W.M.; HAYASHI, C.; FURUYA, V.R.B. et al. Exigência de proteína para alevino revertido de tilápia do Nilo (Oreochromis niloticus). Revista Brasileira de Zootecnia, v.26, n.6, p.1912-1917, 2000 (supl. 1).

FURUYA, W.M.; PEZZATO, L.E.; PEZZATO, A.C. et al. Coeficientes de digestibilidade e valores de aminoácidos digestíveis de alguns ingredientes para tilápia do Nilo (Oreochromis niloticus). Revista Brasileira de Zootecnia v.30, n.4, p.1143-1149, 2001.

FURUYA, W.M.; SILVA, L.C.R.; NEVES, P.R et al. Exigência de metionina + cistina para alevinos de tilápia do Nilo (Oreochromis niloticus). Ciência Rural, v.34, n.6, p.1933-1937, 2004.

HALVER, J.E.; HARDY, R.W. Fish nutrition. 3.ed. Washington: Academic Press, 2002. p.755-769

HAULER, R.C.; CARTER, C.G. Reevaluation of the quantitative dietary lysine requirements of fish. Reviews in Fisheries Science, v.9, n.3, p.133-166, 2001.

HISANO, H.; GONÇALVES, G.S.; ZUANON, J.A.S. et al. Substituição da proteína do farelo de soja pela proteína do glúten de milho em rações para alevinos de tilápia do Nilo. Acta Scientiarum, v.22, n.2, p.255-260, 2003.

JAUNCEY, K.; ROSS, B. A guide to tilapia feed and feeding. Scotland: University of Stirling, 1982. 111p.

KUBITZA, F. Tilápia: tecnologia e planejamento na produção comercial. Jundiaí: F. Kubitza, 2000. 285p.

LANNA, E.A.T.; BOMFIM, M.A.D.; DONZELE, J.L et al. Threonine requirement, base on ideal protein concept, in diets for Nile tilapia (Oreochromis niloticus) fingerlings. In: Aquaculture 2007, San Antonio. Anais... San Antonio: 2007. (CD-ROM).

LANNA, E.A.T.; QUADROS, M.; BOMFIM, M.A.D. et al. Freqüência de alimentação em alevinos de tilápia do Nilo (Oreochromis niloticus) utilizando dietas de baixo teor protéico suplementadas com aminoácidos - resultados preliminares. In: REUNIÃO ANUAL DA SOCIEDADE BRASILEIRA DE ZOOTECNIA, 42., 2005, Goiânia. Anais... Goiânia: Sociedade Brasileira de Zootecnia, 2005. (CD-ROM).

LOSORDO, T.M. Tilapia culture in intensive recirculating systems. In: COSTA-PIERCE, B.; RAKOCY, J. (Eds.). Tilapia aquaculture in the Americas. Baton Rouge: World Aquaculture Society, 1997. v.1, p.185-208.

MACHADO, G.S; FONTES, D.O. Relação entre as exigências nutricionais e o sistema imune em suínos. In: SIMPÓSIO INTERNACIONAL SOBRE EXIGÊNCIAS NUTRICIONAIS DE AVES E SUÍNOS, 2., 2005, Viçosa, MG. Anais... Viçosa, MG: 2005. p.293-314.

NATIONAL RESEARCH COUNCIL - NRC. Nutrient requirements of fish. Washington, D.C.: National Academy of Science, 1993. 105p.

NOBLET, J. Avaliação energética em suínos. In: WORKSHOP LATINO-AMERICANO AJINOMOTO BIOLATINA DE NUTRIÇÃO DE AVES E SUÍNOS, 2001, Foz do Iguaçu. Anais... Foz do Iguaçu: 2001. p.2-17.

ORLANDO, U.A.D.; OLIVEIRA, R.F.M.; DONZELE, J.L et al. Níveis de proteína bruta e suplementação de aminoácidos em rações para leitoas mantidas em ambiente de conforto térmico dos 30 aos 60 kg. Revista Brasileira de Zootecnia, v.34, n.1, p.134-141, 2005.

PEZZATO, L.E.; MIRANDA, E.C.; BARROS, M.M. et al. Digestibilidade aparente de ingredientes pela tilápia do Nilo (Oreochromis niloticus). Revista Brasileira de Zootecnia, v.31, n.4, p.1595-1604, 2002.

RIBEIRO, F.B.; LANNA, E.A.T.; BOMFIM, M.A.D et al. Níveis de fósforo total em dietas para alevinos de tilápia do Nilo. Revista Brasileira de Zootecnia, v.35, n.4, p.1488-1593,2006.

RODEHUTSCORD, M.; BORCHERT, F.; GREGUS, K. et al. Availability and utilization of free lysine in rainbow trout Oncorhynchus mykiss. 1. Effect of dietary crude protein level. Aquaculture, v.187, p.163-176, 2000.

ROSTAGNO, R.S.; ALBINO, L.F.T.; DONZELE, J.L. et al. Tabelas brasileiras para aves e suínos: composição de alimentos e exigências nutricionais. Viçosa, MG: Universidade Federal de Viçosa, 2000. 141p.

ROSTAGNO, R.S.; ALBINO, L.F.T.; DONZELE, J.L. et al. Tabelas brasileiras para aves e suínos: composição de alimentos e exigências nutricionais. 2.ed. Viçosa, MG: Universidade Federal de Viçosa, 2005. 186p.

SILVA, D.J; QUEIROZ, A.C. Análise de alimentos (métodos químicos e biológicos). 3.ed. Viçosa, MG: Universidade Federal de Viçosa, 2002. 235p.

SCHUMACHER, A.; SCHON, J.; GOLDBERG, M. et al. Nonessential amino acid sources in crystalline amino acid diets for trout (Oncorhynchus mykiss). Journal of Applied Ichthyology, v.11, p.317-321, 1995.

TANTIKITTI, C.; MARCH, B.E. Dynamics of plasma free amino acids in rainbow trout (Oncorhynchus mykiss) under variety of dietary conditions. Fish Physiology and Biochemistry, v.14, p.179-194, 1995.

UNIVERSIDADE FEDERAL DE VIÇOSA - UFV. Sistemas de Análises Estatísticas e Genéticas - SAEG. Versão 8.0. Viçosa, MG: 2000. 142p.

WATANABE, W.O.; LOSORDO, T.M.; FITZSIMMONS, K. et al Tilapia production systems in the Americas: technological advances, trend and challenges. Reviews in Fisberies Science, v.10, p.465-498, 2002.

WILSON, R.P. Amino acid requirements of finfish and crustaceans. In: D'MELLO, J.P.F. (Ed.). Amino acid in farm animal nutrition. Wallingford: CAB International, 2003, p.427-447.

YAMAMOTO, T.; SUGITA, T.; FURUITA, H. Essential amino acid supplementation to fish meal-based diets with low protein to energy ratios improves the protein utilization in juvenile raimbow trout (Oncorhinchus mykiss). Aquaculture, v.246, n.1-4, p.379-391, 2005.

ZARATE, D.D.; LOVELL, R.T. Free lysine (L-lysine - $\mathrm{HCl}$ ) is utilized for growth less efficiently than protein-bound lysine (soybean meal) in practical diets by young channel catfish (Ictalurus punctatus). Aquaculture, v.159, p.87-100, 1997.

ZARATE, D.D.; LOVELL, R.T.; PAYNE, M. Effects of feeding frequency and rate of stomach evacuation on utilization of dietary free and protein-bound lysine for growth by channel catfish Ictalurus punctatus. Aquaculture Nutrition, v.5, p.17-22, 1999. 